\title{
Microbially/CO2-derived CaCO3 cement strengthens calcareous sands and its cementation mechanism
}

Xiaoniu Yu ( $\nabla$ xiaoniu.yu@ntu.edu.sg )

Nanyang Technological University

Haoqing Yang

Nanyang Technological University

Qiwei Zhan

Jiangsu University of Science and Technology

\section{Research Article}

Keywords: Carbon dioxide solidification-bacteria, Calcareous sand, MICP, X-ray diffraction, Shear strength, Permeability, Sand

Posted Date: February 22nd, 2022

DOl: https://doi.org/10.21203/rs.3.rs-1364907/v1

License: (c) (i) This work is licensed under a Creative Commons Attribution 4.0 International License. Read Full License 


\section{Abstract}

In this text, a method to use $\mathrm{CO}_{2}$ for the treatment of calcareous sand is presented. Carbon dioxide solidification-bacteria (Streptomyces microflavus) was obtained by screening and applied to the mechanical strengthening of calcareous sand through a microbial mineralization/carbonization process. Experiments in both liquid phase and sand were carried out. The optimal mass ratio of carbon dioxide solidification-bacteria to calcium oxide was found to be 2:1. The optimal dosage of bacterial powder was $30 \%$ of the total dry sand mass. Using the optimal recipe, the average uniaxial compressive strength of treated sand columns was $3.67 \mathrm{MPa}$ and the average permeability coefficient was $4.90 \times 10^{-3} \mathrm{~cm} / \mathrm{s}$. Compared with the other microbial induced carbonate precipitation (MICP) approaches, the proposed method does not release harmful by-products such as ammonia. The chemical composition and microstructure of the treated calcareous sand were characterized by powder X-ray diffraction (XRD) and scanning electron microscopy (SEM). The XRD results showed that the $\mathrm{CO}_{2}$ carbonized product contained mainly calcite.

\section{Introduction}

Reclaimed land and artificial island contain large amounts of calcareous sand and dredger fill. Loose sands and dredger fill are formed by mud pumps of dredgers sucking out mud of seabed. During the filling process of island reef, the structure of calcareous sandy soil is destroyed and slowly deposited in the form of fine particles. Therefore, calcareous sandy soil has the characteristics of high water content, low bearing capacity, large void ratio and high compressibility (Tang et al. 2017). Calcareous sandy soil needs to be reinforced to transform it from a mud state to a foundation with a certain bearing capacity, ready for later construction (Xiao et al. 2017). At present, there are various reinforcement methods for calcareous sandy soil, commonly used vacuum preloading, electro-osmosis, dynamic compaction, chemical methods, etc. These methods can consolidate loose calcareous sandy soil to meet certain engineering design requirements. New methods for strengthening calcareous sandy soil by microbial mineralization have also been reported recently (Kou et al. 2021; Xiao et al. 2016; Dhami et al. 2017; Xiao et al. 2017; Ma et al. 2018; Liu et al. 2019). Microbial mineralization reinforcement technology is the frontier problem of current foundation reinforcement research. It mainly uses microbial mineralization to synthesize inorganic precipitates to bind loose sandy soil particles together ( $Y u$ and Rong, 2022; Kou et al. 2020). In 2005, the biogeotechnology was highlighted by the National Research Council (NRC) as an important research topic in the 21st century.

Microorganisms or cell lysates contain specific biologically active substances, which are capable of converting or decomposing substrates into specific anions, binding to cations under the action of organic substrates, self-assembling into specific structures and functions of materials. Compared with silicate cementitious materials, inorganic carbonate cementitious materials synthesized by microbial mineralization (carbon dioxide solidification-bacteria, CSB) have the following advantages: (1) The products are clean non-toxic, and environmentally friendly; (2) There are wide source of raw materials which are low in cost, such as sugar industry waste can be used as medium, CSB can be extracted from 
soil, etc.; (3) Inorganic cementitious materials mineralized and precipitated by the microbial method have a slower reaction processes compared to chemical methods. Researchers from all over the world have used the MICP technique to bind loose sandy soil grains and conducted in-depth research on the cementation effect (Cheng et al. 2021; Saracho et al. 2021; Wang et al. 2022). The inorganic cementitious materials synthesized by microbial mineralization act as a "bridge" to connect the loose sandy soil particles. (Akiyama and Kawasaki, 2012; Cheng et al. 2014; Montoya and Dejong, 2015; Jiang and Soga, 2017; Agereh et al. 2019; Gao et al. 2019; Li et al. 2019; Qian et al. 2018; Yu et al. 2019). The MICP technique has a great potential to change the engineering behavior of the soil and can be used in soil improvement or liquefaction mitigation. (Montoya and Dejong, 2015; Xiao et al. 2018).

Most of the existing researchers have focused on the MICP including the effect of cementation and its influencing factors, but little research has been conducted on other types of microbial mineralization (Li et al. 2015; Yu et al. 2015; Dhami et al. 2017; Zhan and Qian, 2017). This study uses the inorganic carbonate cementitious material formed by microbial mineralization/carbonization to reinforce calcareous sands, which has a value of engineering application and theoretical research. This type of material has the characteristics of pure natural and pollution-free which is in line with the development of sustainable construction materials. A series of liquid phase and sand column tests were conducted to opt for the optimal recipe of microbial mineralization/carbonation process. Engineering property test such as uniaxial compressive strength and permeability test were carried out on both the microbial mineralization/carbonation cemented sand and chemical carbonation cemented sand. The comparison of testing results indicate that the microbial mineralization/carbonation process was able to reduce the permeability of calcareous sand and enhance its strength at the same time.

\section{Microbial Mineralization/carbonization Mechanism}

In nature, the direct hydration of $\mathrm{CO}_{2}$ can produce $\mathrm{H}_{2} \mathrm{CO}_{3}$, which can be finally ionized to $\mathrm{HCO}_{3}{ }^{-}$and $\mathrm{CO}_{3}{ }^{2-}$. The natural process is slow and the formation of $\mathrm{H}_{2} \mathrm{CO}_{3}$ can take a long time to complete (Kanth et al. 2012). However, this process can be accelerated. Using the catalysis of carbonic anhydrase (CA) secreted by specific microorganisms, the hydration reaction rate of $\mathrm{CO}_{2}$ can be increased $10^{7}$ times or more (Kanth et al. 2012; Qian et al. 2021; Sun and Alkon 2002; Xiao and Lian 2016).

In this case, large number of $\mathrm{H}_{2} \mathrm{CO}_{3}$ can be prepared and available for further applications (Tripp et al. 2001; Dhami et al. 2014; Zhan and Qian, 2016a; Zhan and Qian, 2016b; Zhan and Qian, 2017). In this study, the carbonic anhydrase-bacteria (CAB) was used to generate carbonate for the formation of calcium carbonate. The process is shown in Fig. 1 (Dhami et al. 2017; Zhan and Qian, 2017). The carbonic anhydrase could be harvested during the cultivation of Streptomyces microflavus which can be used to capture carbon dioxide from the air to produce bicarbonate ions through the hydration of carbon dioxide. The mineralization reaction of calcium ions and bicarbonate ions nucleates on the surface of the microbial cells and then deposits calcium carbonate particles. Bio-chemical reaction equations (1-9) for 
the microbial mineralization/carbonization of calcium nitrate and calcium oxide by Streptomyces microflavus solution are as follows:

Bacteria $+\mathrm{CO}_{2} \leftrightarrow$ Bacteria- $\mathrm{CO}_{2}(1)$

Bacteria- $\mathrm{CO}_{2}+\mathrm{H}_{2} \mathrm{O} \leftrightarrow$ Bacteria $+\mathrm{H}_{2} \mathrm{CO}_{3}(2)$

$\mathrm{H}_{2} \mathrm{CO}_{3} \leftrightarrow \mathrm{HCO}_{3}^{-}+\mathrm{H}^{+}(3)$

$\mathrm{HCO}_{3}{ }^{-} \leftrightarrow \mathrm{CO}_{3}{ }^{2-}+\mathrm{H}^{+}(4)$

$\mathrm{Ca}\left(\mathrm{NO}_{3}\right)_{2} \leftrightarrow \mathrm{Ca}^{2+}+2 \mathrm{NO}_{3}^{-}(5)$

$\mathrm{CaO}+\mathrm{H}_{2} \mathrm{O} \leftrightarrow \mathrm{Ca}(\mathrm{OH})_{2}(6)$

$\mathrm{Ca}(\mathrm{OH})_{2} \leftrightarrow \mathrm{Ca}^{2+}+2 \mathrm{OH}^{-}(7)$

$\mathrm{CO}_{3}{ }^{2-}+\mathrm{Ca}^{2+}=\mathrm{CaCO}_{3}(\mathrm{~s})(8)$

$\mathrm{OH}^{-}+\mathrm{H}^{+} \leftrightarrow \mathrm{H}_{2} \mathrm{O}(9)$

\section{Material And Methods}

\subsection{Materials}

All raw materials were of analytically pure grade without further purification. Streptomyces microflavus powder was purchased from Zhengzhou lebeifeng Biotechnology Co., Ltd., China. Calcareous sand was obtained from Fujian province, China. The particle size of calcareous sand was mainly distributed between 0.1 and $2 \mathrm{~mm}$, and the average particle size was $0.549 \mathrm{~mm}$, as shown in Table 1 and Fig. 2 .

Table 1

Properties of calcareous sand.

\begin{tabular}{|c|c|c|c|c|c|c|}
\hline $\begin{array}{l}\text { Sand } \\
\text { gradation }\end{array}$ & $\begin{array}{l}\text { Mean } \\
\text { grain size } \\
\left(D_{50}, \mathrm{~mm}\right)\end{array}$ & $\begin{array}{l}\text { Coefficient } \\
\text { of } \\
\text { uniformity } \\
\left(C_{u}\right)\end{array}$ & $\begin{array}{l}\text { Coefficient } \\
\text { of } \\
\text { curvature } \\
\left(C_{c}\right)\end{array}$ & $\begin{array}{l}\text { Specific } \\
\text { gravity } \\
\left(G_{s}\right)\end{array}$ & $\begin{array}{l}\text { Maximum void } \\
\text { ratio }\left(e_{\max }\right)\end{array}$ & $\begin{array}{l}\text { Minimum void } \\
\text { ratio }\left(e_{\min }\right)\end{array}$ \\
\hline C & 0.549 & 2.293 & 0.981 & 2.854 & 1.235 & 0.775 \\
\hline
\end{tabular}

Cultivation of Streptomyces microflavus: $5 \mathrm{~g}$ of beef extract and $3 \mathrm{~g}$ of peptone were added to $1 \mathrm{~L}$ of deionized water, stirred evenly, and the $\mathrm{pH}$ of the solution was adjusted to about 7. The medium solution was equally divided into 2 portions $(500 \mathrm{~mL}$ each) and poured into a $1 \mathrm{~L}$ Erlenmeyer flask. Approximately $15 \otimes 20 \mathrm{~g}$ of bacterial pellets were obtained through centrifuging $1 \mathrm{~L}$ of bacterial solution (Yu and Jiang, 
2019). $10 \mathrm{~g}$ of Streptomyces microflavus powder was added to each medium solution, shaken, and cultivated aseptically in the incubator shaker $\left(170 \mathrm{rpm}, 29.3 \pm 1^{\circ} \mathrm{C}\right)$ for $24 \mathrm{~h}$. After $24 \mathrm{~h}$, all bacterial solution was kept in a refrigerator at $4 \pm 1^{\circ} \mathrm{C}$ for stock prior to use. The concentration of carbonic anhydrase in Streptomyces microflavus solution (3 samples) is $7.427,7.671$, and $8.239 \mathrm{ng} / \mathrm{mL}$ according to test results of ELISA Kit. The average concentration of carbonic anhydrase is $7.779 \pm 0.34 \mathrm{ng} / \mathrm{mL}$ in Streptomyces microflavus solution.

\subsection{Mineralization/carbonization of calcium ions}

Different contents of calcium oxide $(\mathrm{CaO})$ and calcium nitrate $\left(\mathrm{Ca}\left(\mathrm{NO}_{3}\right)_{2}\right)(0.5$ and $1 \mathrm{~g})$ were added to $100 \mathrm{~mL}$ of Streptomyces microflavus solution at room temperature and in the air. Concentration of calcium ions was measured by atomic absorption spectroscopy during the mineralization period $(0,5,9$, 14, 21, and 28d). The precipitated materials were dried and collected for powder XRD analysis.

\subsection{Preparation of sand specimens}

Cementation of calcareous sand was carried out in sand columns with Streptomyces microflavus powder and calcium oxide. The mass ratio of Streptomyces microflavus powder to calcium oxide was 2:1. The medium solution ( $10 \mathrm{~g} / \mathrm{L}$ of beef extract and $6 \mathrm{~g} / \mathrm{L}$ of peptone) was added to calcareous sand columns. A certain amount of bacterial powders, calcium oxide, and calcareous sand were weighed and mixed with medium solution to make 6 groups of sand columns $(\Phi 5 \mathrm{~cm} \times 10 \mathrm{~cm})$, as shown in Fig. 3 . There were 3 sand columns in each group. Under the same conditions of the amount of calcium oxide, 6 groups of control sand columns were prepared without adding bacteria powder. The medium solution was sprayed for 5 times in every 3 hours within $24 \mathrm{~h}$ after all the sand columns were made. Then, all the sand columns were placed in a carbonization box for curing, and sprayed 5 times of medium solution in the morning, noon and night, for 7 days. The carbonization tank had a carbon dioxide concentration of $20 \pm 1 \%$, a humidity of $70 \pm 5 \%$, and a temperature of $20 \pm 2^{\circ} \mathrm{C}$. After $7 \mathrm{~d}$, all sand columns were taken out and placed in an oven $\left(60 \pm 2^{\circ} \mathrm{C}\right)$ for drying prior to further testing.

\subsection{Characterization}

The concentration of calcium ions was determined by atomic absorption spectroscopy (AA6880, Shimadzu Corporation, Japan) (Shao et al., 2018; Yu and Jiang, 2019). The composition of the calcareous sand and sand column was characterized by powder X-ray diffraction analysis (XRD, 40 kV, 40 mA; Bruker Company, Karlsruhe, Germany) (Shao et al., 2018). The morphology of the samples was observed by scanning electron microscopy (SEM, JOEL, JSM-6700F, Tokyo, Japan). The uniaxial compressive strength of sand columns was tested by the ordinary compression/bending test machine (Yu and Sun, 2018). The permeability of sand columns was measured by a flexible wall permeameter (Samingan et al., 2003; Yu et al., 2019). Permeability tests of sand columns $(\$ 5 \mathrm{~cm} \times 2 \mathrm{~cm})$ were carried out according to the methods of the patent and literature (China Patent 2007; Kang and Shackelford, 2009), as shown in Fig. 4. 
After the sample was installed, water was injected into the pressure chamber, and the upper and lower ends of the support were subjected to a bubble discharge operation. The confining pressure was adjusted to $35 \mathrm{kPa}$, and the water head of drop tube was added to $1.5 \mathrm{~m}$ to discharge air bubbles (China Academy of Building Research 2016). After that, the titration tube water was again raised to $1.5 \mathrm{~m}$, and the sample was saturated for $48 \mathrm{~h}$. The permeation test was started after the sample was saturated, and the number of times was recorded at intervals of $30 \mathrm{~min}$. The reading interval was self-controlled based on the permeation rate of the solution, the exudate was collected in a graduated cylinder, and the readings of time, burette, and graduated cylinder were recorded, respectively. The permeability of sand columns was calculated according to the Eq. (10) (China Academy of Building Research 2016):

$k=a L / 2 A \Delta t \times \ln \left(H_{1} / H_{2}\right)(10)$

Where $k$ was the permeability of the sample, $\mathrm{cm} / \mathrm{s}$; $a$ was the inner diameter area of the variable water burette, $\mathrm{cm}^{2} ; L$ was the height of the sample, $\mathrm{cm} ; \Delta t$ was the time interval, $\mathrm{s} ; H_{1}, H_{2}$ were the starting and ending burette readings, respectively, $\mathrm{cm}$.

\section{Results And Discussion}

\subsection{Calcium ions of microbial mineralization/carbonization}

The changes of calcium ion concentrations from $\mathrm{Ca}\left(\mathrm{NO}_{3}\right)_{2}$ and $\mathrm{CaO}$ due to microbial mineralization/carbonation were shown in Table 1. Table 1 showed that the optimum mineralization time and content of calcium nitrate were 9 days and $0.5 \mathrm{~g}$, respectively. When the mass of calcium nitrate was bigger than 1g, the enzyme activity of Streptomyces microflavus was inhibited and could not capture carbon dioxide. In the presence of calcium nitrate, the bacteria began to lysis after 9 days, and calcium ions attached on the cell wall began to diffuse, resulting in an increase in the concentration of calcium ions in the solution. Overall, calcium ions can be removed by the microbial mineralization/carbonization in the air.

The optimum mineralization time and dosage of calcium oxide were 21 days and $1 \mathrm{~g}$, respectively, as shown in Table 1. The calcium hydroxide was slightly soluble in water, and the concentration of calcium ions after hydrolysis at different times was different with carbonization of calcium ions. In general, calcium ions could be carbonized and deposited according to the changes in calcium ions concentration for 14 days and 21 days. In the presence of calcium oxide, the bacteria began to lysis after 21 days, and the calcium ion concentrations also increased. The mass ratio of Streptomyces microflavus powder to calcium oxide was 2:1. Therefore, the ratio was applied to bind loose calcareous sand grains. Due to the low concentration of carbon dioxide in the air (accounting for an air volume fraction of $0.03 \%$ ), the carbonization time could be shortened when a higher carbon dioxide concentration was available. Therefore, the carbonization time could be selected for 7days in the high concentration of carbon dioxide in sand columns experiment. 
Powder XRD results showed that the products were mainly calcite $\left(\mathrm{CaCO}_{3}\right.$, PDF Card No. 72-1652) when calcium sources were from $\mathrm{Ca}\left(\mathrm{NO}_{3}\right)_{2}$ and $\mathrm{CaO}$, as shown in Figs. $5 \mathrm{a}$ and $5 \mathrm{~b}$.

Table 2

Calcium ions $\left(\mathrm{Ca}^{2+}, \mathrm{mg} / \mathrm{L}, \mathrm{Ca}\left(\mathrm{NO}_{3}\right)_{2}\right.$ and $\left.\mathrm{CaO}\right)$ concentration under different days of the microbial mineralization/carbonization in the air.

\begin{tabular}{|llllll|}
\hline $\mathrm{Ca}\left(\mathrm{NO}_{3}\right)_{2}(\mathrm{~g})$ & $\mathbf{0 . 5}$ & $\mathbf{1}$ & $\mathrm{CaO}(\mathrm{g})$ & $\mathbf{0 . 5}$ & $\mathbf{1}$ \\
\hline $0 \mathrm{~d}$ & $325.48 \pm 0.9$ & $1016.17 \pm 1.39$ & $0 \mathrm{~d}$ & $108.46 \pm 1.05$ & $67.53 \pm 2.08$ \\
\hline $5 \mathrm{~d}$ & $55.29 \pm 1.01$ & $1050.3 \pm 16.59$ & $5 \mathrm{~d}$ & $128.12 \pm 3.65$ & $691.86 \pm 6.15$ \\
\hline $9 \mathrm{~d}$ & $8.49 \pm 0.1$ & $1054.5 \pm 22.28$ & $9 \mathrm{~d}$ & $69.59 \pm 0.47$ & $1040.94 \pm 9.28$ \\
\hline $14 d$ & $24.22 \pm 0.01$ & $1163.2 \pm 6.52$ & $14 \mathrm{~d}$ & $86.06 \pm 0.59$ & $560.16 \pm 4.34$ \\
\hline $21 d$ & $30.47 \pm 0.06$ & $2658.76 \pm 1.24$ & $21 d$ & $59.32 \pm 0.25$ & $64.48 \pm 0.46$ \\
\hline $28 d$ & $23.82 \pm 0.49$ & $1745.63 \pm 25.8$ & $28 d$ & $43.90 \pm 0.21$ & $331.73 \pm 2.83$ \\
\hline
\end{tabular}

\subsection{Properties and chemical composition of calcareous sand}

The powder XRD of calcareous sand were shown in Fig. 5. The powder XRD results of calcareous sand showed that the main chemical component of calcareous sands was $\mathrm{CaCO}_{3}$ (Aragonite) according to PDF Card No. 99 - 0013 (Fig. 6). SEM images of Figs. 7a and 7b show that the surface of calcareous sand was rough and porous. Figures $7 \mathrm{c}$ and $7 \mathrm{~d}$ indicate that the morphology of Streptomyces microflavus was a short rod-like structure with a size of approximately $2 \varangle 4 \mu \mathrm{m}$.

\subsection{Chemical compositions and microstructure of sand columns}

Based on powder XRD analysis of the sand column, Fig. 8 shows that calcite (PDF Card No. 72-1937) and aragonite (Aragonite, PDF Card No. 75-2230) were formed under the optimal dosage of bacterial powder (30\%). Calcite (PDF Card No. 81-2027) and aragonite (Aragonite, PDF Card No. 75-2230) also appeared in sand columns cemented by chemical carbonization (Fig. 9). Therefore, cementitious materials produced by microbial mineralization/carbonization and chemical carbonization were mainly calcite and aragonite, which could effectively bind loose calcareous sand particles (Figs. 8 and 10). SEM images indicated that a portion of cementitious materials formed a whole piece through chemical carbonization, while others were connected to each other individually, as shown in Figs. 10a and b. In contrast, the cementitious materials produced by microbial mineralization/carbonization were all in one piece, as shown in Figs. 10c and $d$. Therefore, sand columns were cemented by microbial mineralization/carbonization compared with chemical carbonization. 


\subsection{Strength of sand columns}

As shown in Fig. 11, the process of microbial carbonization/mineralization of calcareous sand, including microbial spore germination, microbial growth and reproduction, carbon dioxide diffusion, bicarbonate infiltration and mineralized calcite deposition and cementation took place in a carbonization chamber (After Zhan, 2018). In the carbonization tank, the loose calcareous sand particles were cemented through the bindings formed by the carbonization process. The average uniaxial compressive strength of sand columns cemented by chemical carbonization and microbial mineralization/carbonization were shown in Fig. 11. When the content of calcium oxide was $15 \%$, the average uniaxial compressive strength of sand columns reached the peak in the microbial mineralization/carbonization. The optimum amount of bacterial powder usage was $30 \%$ according to mass of calcium oxide in terms of strength obtained. Without calcium oxide, there was no strength in the sand columns only contained bacterial powder. The average uniaxial compressive strength of sand columns cemented by chemical carbonization was maximum when the content of calcium oxide was $25 \%$. Compressive strength of sand columns prepared by microbial mineralization/carbonization method is above that of chemical carbonization, as shown in Fig. 12. It seems that the bacterial powder was beneficial to the microbial mineralization/carbonization process of calcium oxide. When the amount of calcium oxide was less than $15 \%$, the uniaxial compressive strength increased with the powder content of increase. However, as the content of calcium oxide exceeded $15 \%$, the strength changed in the opposite direction in the microbial mineralization/carbonization. The overall activity of the bacteria may be affected due to the excessive amount of bacterial powder usage, leading to the decrease of strength.

\subsection{Density of sand columns}

Figure 12 showed average densities of sand columns tested after chemical carbonization and biomineralization/carbonization. Average densities of sand columns cemented by chemical carbonization method were $1.50,1.55,1.65,1.66$, and $1.75 \mathrm{~g} / \mathrm{cm}^{3}$, when contents of CaO were $10 \%, 15 \%, 20 \%, 25 \%$, and $30 \%$, respectively. Average densities of sand columns cemented by bio-mineralization/carbonization

method were $1.50,1.59,1.52,1.55$, and $1.60 \mathrm{~g} / \mathrm{cm}^{3}$, when contents of CaO were $10 \%, 15 \%, 20 \%, 25 \%$, and $30 \%$, respectively. By comparison, the average densities of sand columns cemented by biomineralization/carbonization method were similar to that of the chemical carbonization cemented when content of $\mathrm{CaO}$ was identical. Therefore, there was no regularity between densities and compressive strength of sand columns.

\subsection{Permeability of sand columns}

The permeability coefficient tests of sand columns under different conditions were showed in Fig. 14 . Test results showed that the average permeability of sand columns cemented by microbial mineralization/carbonization and chemical carbonization was $4.90 \times 10^{-3} \mathrm{~cm} / \mathrm{s}$ and $9.01 \times 10^{-3} \mathrm{~cm} / \mathrm{s}$, respectively. Initial average permeability of sand columns was $4.60 \times 10^{-2} \mathrm{~cm} / \mathrm{s}$. The average permeability of sand columns cemented by microbial mineralization/carbonization and chemical carbonization could be obviously reduced compared with the initial average permeability. The average permeability coefficient 
of sand columns cemented by MICP as $3.10 \times 10^{-3} \mathrm{~cm} / \mathrm{s}$ at the nearest injection port $(0 \sim 10 \mathrm{~cm})$, was $4.90 \times 10^{-3} \mathrm{~cm} / \mathrm{s}$ at $10 \sim 20 \mathrm{~cm}$ (Rong, 2014, Rong et al., 2014). The results indicate that average permeability coefficient of sand columns cemented by the microbial mineralization/carbonization was comparable to that of the MICP cemented at injection port of $10 \sim 20 \mathrm{~cm}$.

\subsection{Potential applications in the field of construction materials}

Microbial capture of carbon dioxide can be used to prepare high-performance building materials and improve durability, for example, to prepare building materials, cement-based materials to resist efflorescence/self-repair, and to suppress dust on construction sites, as shown in Fig. 15. Microbial capture of carbon dioxide can convert calcium or magnesium ions in building materials into carbonates with cementitious properties, which can improve the mechanical properties and aesthetic functions of construction materials, and at the same time can achieve carbon sequestration (Qian et al. 2015; Xue and Qian 2015; Qian et al. 2016; Wang et al. 2016; Zhan et al., 2020). The specific potential application areas are as follows: (1) The CAB can accelerate the carbonization efficiency of $\mathrm{CO}_{2}$, it can be added to the smelting waste slag containing calcium or magnesium. In the presence of a certain amount of carbon dioxide, the strength of the waste slag specimens can be significantly improved. (2) The CAB is absorbed in a carrier and can be added to the strong alkaline cement-based wallboard mortar. In the presence of carbon dioxide, it can inhibit the migration of $\mathrm{Ca}^{2+}$ in the middle of the cement-based material to the surface of the wallboard, thereby improving the anti-efflorescence ability. (3) The CAB is encapsulated in the carrier and can be added to the strong alkaline cement-based material. In the presence of carbon dioxide, the $\mathrm{Ca}^{2+}$ at the cracks in the cement-based material can be mineralized into calcium carbonate and filled in the cracks for improve its durability. (4) The mixed solution of CAB and calcium nitrate is sprayed on the surface of the dust on the construction site. In the presence of atmospheric carbon dioxide, a consolidation layer can be formed on the surface of the dust, thereby improving it resistance to wind erosion, and the entire biological mineralization/carbonization process is environmentally friendly.

\section{Conclusions}

Loose calcareous sand grains were cemented by microbial mineralization/carbonization in this study. Powder XRD analysis showed that mineral phases of the cementitious materials formed within sand grains were mainly calcite and aragonite. These bindings connected loose calcareous sand particles together and provided a certain mechanical strength. The highest uniaxial compressive strength of sand columns cemented was microbial mineralization/carbonization 3.67MPa when the mass ratio of Streptomyces microflavus powder to calcium oxide was 2:1 and the optimal dosage of the bacterial powder was $30 \%$. By contrast, the average uniaxial compressive strength of sand columns cemented by chemical carbonization was only $1.80 \mathrm{MPa}$. Under the optimal content of the bacterial powder, the permeability coefficient of sand columns cemented by microbial mineralization/carbonization was $4.90 \times 10^{-3} \mathrm{~cm} / \mathrm{s}$ and the permeability coefficient of sand columns cemented by chemical carbonization 
was $9.01 \times 10^{-3} \mathrm{~cm} / \mathrm{s}$. The microbial mineralization/carbonization technology has the potential to be applied for the purpose of island reef reinforcement, foundation reinforcement, desert sand solidification, and so on.

\section{Declarations}

\section{Author contribution}

XN collected, reviewed, and wrote the manuscript. HQ and QW contributed to conceiving and revising the manuscript.

\section{Conflict of interest}

The authors declare no conflict of interest.

\section{Acknowledgments}

The research described in this paper was financially supported by the Opening Funds of Jiangsu Key Laboratory of Construction Materials (grant No. CM2018-02) and the National Natural Science Foundation of China (grant No. 51702238). Their financial support is gratefully acknowledged.

\section{References}

1. Agereh SR, Kiani F, Khavazi K, Rouhipour $H$, Khormali $F$ (2019) An environmentally friendly soil improvement technology for sand and dust storms control. Environ. Eng. Manag. J. 6(2019) 63-71

2. Akiyama M, Kawasaki S (2012) Microbially mediated sand solidification using calcium phosphate compounds. Eng Geol 137-138:29-39

3. Cheng YJ, Tang CS, Pan XH, Liu B, Xie YH, Cheng Q, Shi B (2021) Application of microbial induced carbonate precipitation for loess surface erosion control. Eng Geol 294:106387

4. China Academy of Building Research (2006) JG/T 193-2006, Sodium bentonite geosynthetic clay liner. Construction industry standard of the People's Republic of China

5. China Patent (2007) CN201710729930, Multi-connected flexible wall permeameter

6. Cheng L, Shahin M, Cord-Ruwisch R (2014) Bio-cementation of sandy soil using microbially induced carbonate precipitation (MICP) for marine environments. Géotechnique 64(2014) 1010-1013

7. Dhami NK, Alsubhi WR, Watkin E, Mukherjee A (2017) Bacterial community dynamic sand biocement formation during stimulation and augmentation: Implications for soil consolidation. Front Microbiol 8:1267

8. Dhami NK, Mukherjee A, Reddy MS (2016) Micrographical, minerological and nano-mechanical characterisation of microbial carbonates from urease and carbonic anhydrase producing bacteria. Ecol Eng 94:443-454 
9. Dhami NK, Reddy MS, Mukherjee A (2014) Synergistic role of bacterial urease and carbonic anhydrase in carbonate mineralization. Appl Biochem Biotechnol 172:2552-2561

10. Jiang NJ, Soga K (2017) The applicability of microbially induced calcite precipitation (MICP) for internal erosion control in gravel-sand mixtures. Géotechnique 67:42-55

11. Kang JB, Shackelford CD (2009) Clay membrane testing using a flexible-wall cell under closedsystem boundary conditions. Appl Clay Sci 44:43-58

12. Kanth BK, Min K, Kumari S, Jeon H, Jin ES, Lee J, Pack SP (2012) Expression and characterization of codon-optimized carbonic anhydrase from dunaliella species for $\mathrm{CO}_{2}$ sequestration application. Appl Biochem Biotech 167:2341-2356

13. Kou HL, Diao WZ, Zhang WC, Zheng JB, Ni P, Jiang BA, Wu C (2021) Experimental study of interface shearing between calcareous sand and steel plate considering surface roughness and particle size. Appl Ocean Res 107:102490

14. Kou HL, Wu CZ, Ni PP, Jang BA (2020) Assessment of erosion resistance of biocemented sandy slope subjected to wave actions. Appl Ocean Res 105:102401

15. Li C, Wang YX, Zhou TJ, Bai S, Gao Y, Yao D, Li L (2019) Sulfate acid corrosion mechanism of biogeomaterial based on MICP technology. J Mater Civil Eng 31:04019097

16. Liu L, Liu H, Stuedlein AW, Evans TM, Xiao Y (2019) Strength, stiffness, and microstructure characteristics of biocemented calcareous sand. Can Geotech J 00:1-12

17. Li M, Fu Q, Zhang Q, Achal V, Kawasaki S (2015) Bio-grout based on microbially induced sand solidification by means of asparaginase activity. Sci Rep 5:16128

18. Ma RN, Guo HX, Cheng XH, Liu JR (2018) Permeability experiment study of calcareous sand treated by microbially induced carbonate precipitation using mixing methods. Rock and Soil Mechanics 39:217-223

19. Montoya BM, Dejong JT (2015) Stress-strain behavior of sands cemented by microbially induced calcite precipitation. J Geotech Geoenviron 141:04015019

20. Qian CX, Chen HC, Ren LF, Luo M (2015) Self-healing of early age cracks in cement-based materials by mineralization of carbonic anhydrase microorganism, Front. Microbiol. 6(2015) 1225

21. Qian CX, Ren LF, Xue B, Cao T (2016) Bio-mineralization on cement-based materials consuming $\mathrm{CO}_{2}$ from atmosphere. Constr Build Mater 106:126-132

22. Qian CX, Yu XN, Wang X (2018) A study on the cementation interface of bio-cement. Mater Charact $136: 122-127$

23. Qian CX, Yu XN, Zheng TW, Chen Y, Y.Q (2022) Review on bacteria fixing $\mathrm{CO}_{2}$ and bio-mineralization to enhance the performance of construction materials. J CO2 Util 55:101849

24. Rong H (2014) Preparation and binding mechanism of microbe cement. Dissertation, Southeast University, China

25. Rong H, Qian CX, Wang X (2014) Performance of microbe cementitious materials. J Funct Mater 45:11091-11095

Page 11/19 
26. Samingan AS, Leong EC, Rahardjo H (2003) A flexible wall permeameter for measurements of water and air coefficients of permeability of residual soils. Can Geotech J 40:559-574

27. Saracho AC, Haigh SK, Jorat ME (2021) Flume study on the effects of microbial induced calcium carbonate precipitation (MICP) on the erosional behaviour of fine sand. Geotechnique 17:1135-1149

28. Shao JC, Yu XN, Zhou M, Cai XQ, Yu C (2018) Nanoscale zero-valent iron decorated on bentonite/graphene oxide for copper ions removal from aqueous solution. Materials 11:945

29. Sun MK, Alkon DL (2002) Carbonic anhydrase gating of attention: memory therapy and enhancement. Trends Pharmacol Sci 23:83-89

30. Tang LS, Song J, Chen HK, Wang Y, Yin JL, Ye JL (2017) Impacts of organic content and pH on consolidation of clayey dredger fill by vacuum preloading method. Geosci J 21:765-778

31. Tripp BC, Smith K, Ferry JG (2001) Carbonic anhydrase: new insights for an ancient enzyme. J Biol Chem 276:48615-48618

32. Wang K, Qian C, Wang R (2016) The properties and mechanism of microbial mineralized steel slag bricks. Constr Build Mater 113:815-823

33. Wang ZY, Zhang JH, Li Q, Zhang N, Feng WJ (2022) A theoretical thermal conductivity model for soils treated with microbially induced calcite precipitation (MICP). Int J Heat Mass Tran 183:122091

34. Xiao LL, Lian B (2016) Heterologously expressed carbonic anhydrase from Bacillus mucilaginosus promoting $\mathrm{CaCO}_{3}$ formation by capturing atmospheric $\mathrm{CO}_{2}$. Carbonate Evaporite 31:39-45

35. Xiao P, Liu HL, Xiao Y, Stuedlein AW, Evans TM (2018) Liquefaction resistance of bio-cemented calcareous sand. Soil Dyn Earthq Eng 107:9-19

36. Xiao Y, Liu HL, Chen Q, Ma Q, Xiang Y, Zheng Y (2017) Particle breakage and deformation of carbonate sands with wide range of densities during compression loading process. Acta Geotech 12:1177-1184

37. Xue B, Qian C (2015) Mitigation of efflorescence of wallboard by means of bio-mineralization. Front Microbiol 6:1155

38. Yu C, Liao RP, Cai XQ, Yu XN (2019) 2019. Sodium polyacrylate modified method to improve permeant performance of bentonite in chemical resistance. J Clean Prod 213:242-250

39. Yu XN, Jiang JG (2019) Phosphate microbial mineralization removes nickel ions from electroplating wastewater. J Environ Manage 245:447-453

40. Yu XN, Qian CX, Xue B, Wang X (2015) The influence of standing time and content of the slurry on bio-sandstone cemented by biological phosphates. Constr Build Mater 82:167-172

41. Yu XN, Qian CX, Jiang JG (2019) Desert sand cemented by bio-magnesium ammonium phosphate cement and its microscopic properties. Constr Build Mater 200:116-123

42. Yu XN, Rong H (2022) Seawater based MICP cements two-phase/one-phase cemented sand blocks. Appl Ocean Res 118:102972

43. Yu XN, Sun LZ (2018) Strength, microstructure, and thermal conductivity of the insulation wallboards prepared with rice husk fiber and recycled concrete aggregates. PLoS ONE 13:e0203527 
44. Zhan QW (2018) Cementation of sandy soil by shallow mineralization of microbe capturing carbon dioxide and application in fugitive dust suppression. Dissertation, Southeast University, China

45. Zhan QW, Qian CX (2016a) Depth evolution of mechanical properties of fugitive dust cemented by microbe cement based on $\mathrm{CO}_{2}$ capture. Adv Cem Res 28:494-502

46. Zhan QW, Qian CX (2016b) Effect of treatment process on consolidation efficiency of fugitive dust cemented by bio-activated cementitious material based on $\mathrm{CO}_{2}$ capture. Sci China Technol Sc 59:1194-1200

47. Zhan QW, Qian CX (2017) Stabilization of sand particles by bio-cement based on $\mathrm{CO}_{2}$ capture and utilization: process, mechanical properties and microstructure. Constr Build Mater 133:73-80

48. Zhan Q, Yu X, Zhang S, Xu Y, Pan Z, Qian C (2020) Study on improving the consolidation properties of microbial cementitious material by promoting spore germination ratio. Constr Build Mater 252:119036

\section{Figures}

\section{Figure 1}

The formation process of calcium carbonate.

\section{Figure 2}

Particle size distribution of calcareous sand particles.

\section{Figure 3}

Calcareous sand columns after molding. 


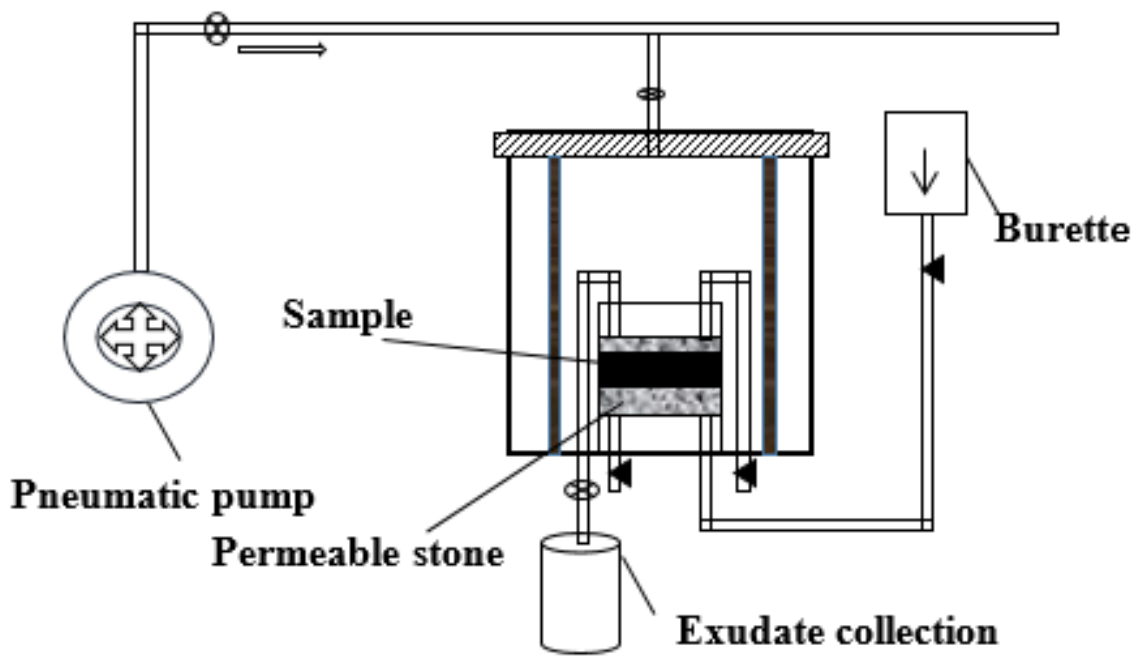

Figure 4

Permeability tests of sand columns cemented by microbial mineralization/carbonization and chemical carbonization. 


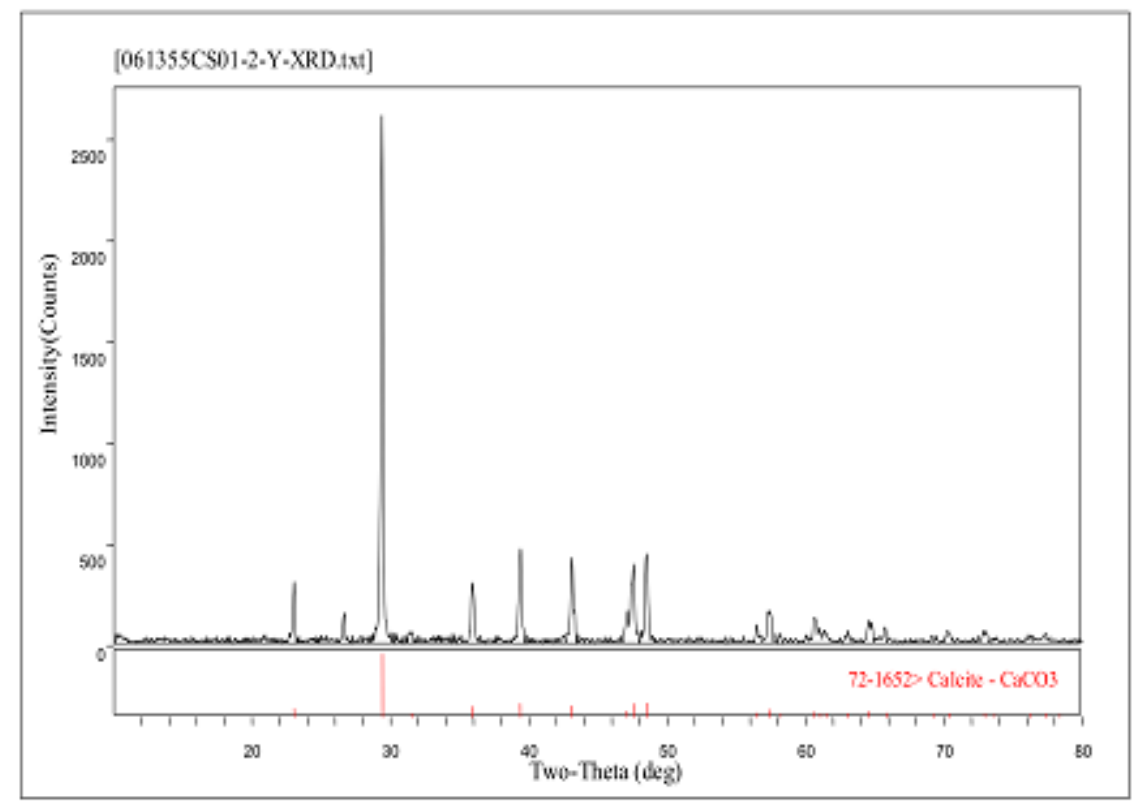

(a)

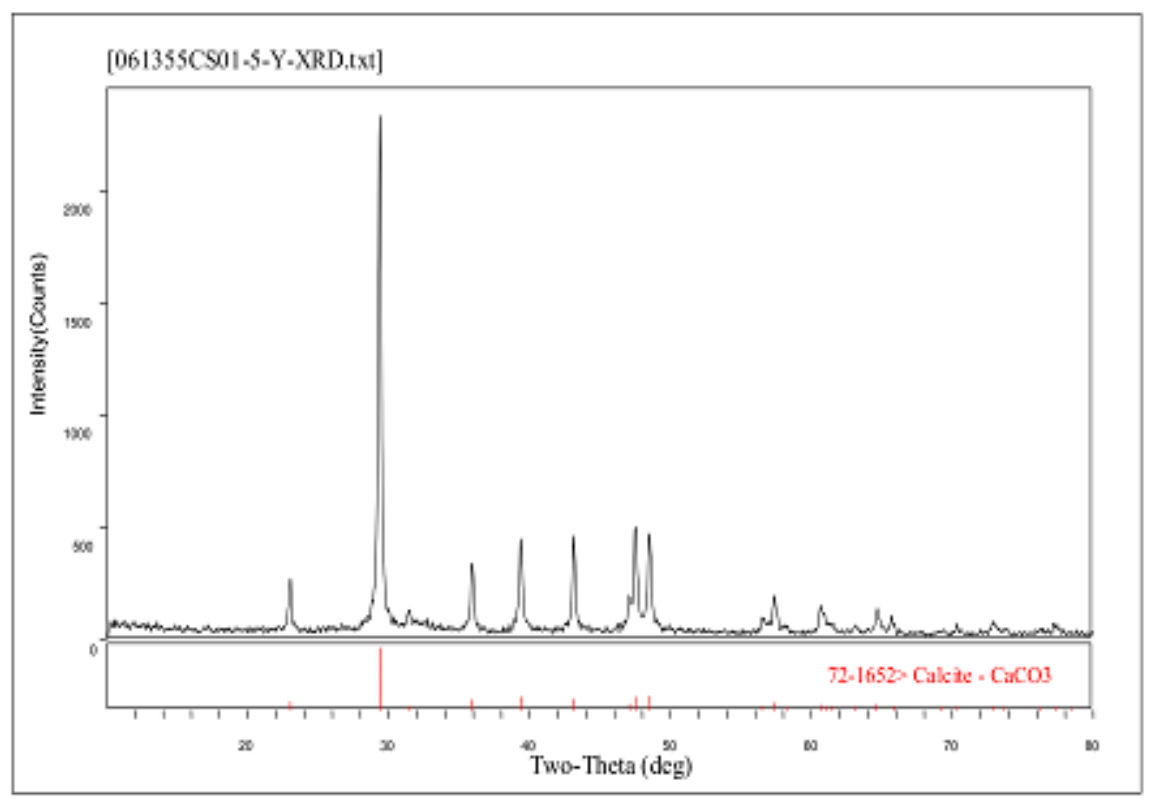

(b)

\section{Figure 5}

XRD patterns of microbial mineralization/carbonization for calcium nitrate (a) and calcium oxide (b). 


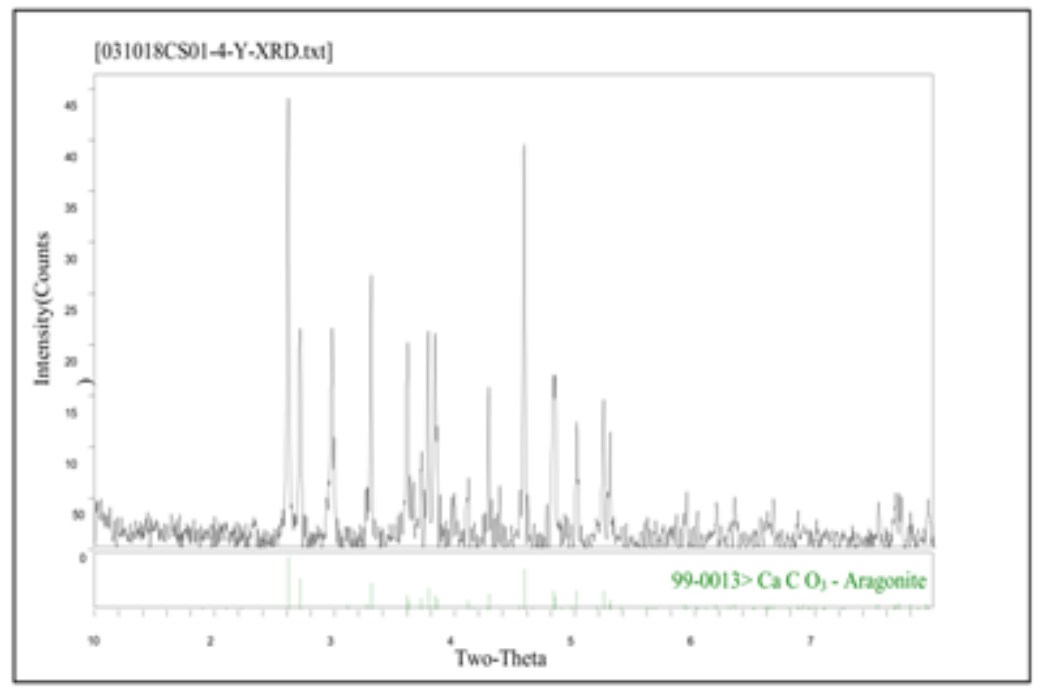

Figure 6

XRD pattern of calcareous sand particles.

Figure 7

SEM images of calcareous sand $(a, b)$ and Streptomyces microflavus (c, d).

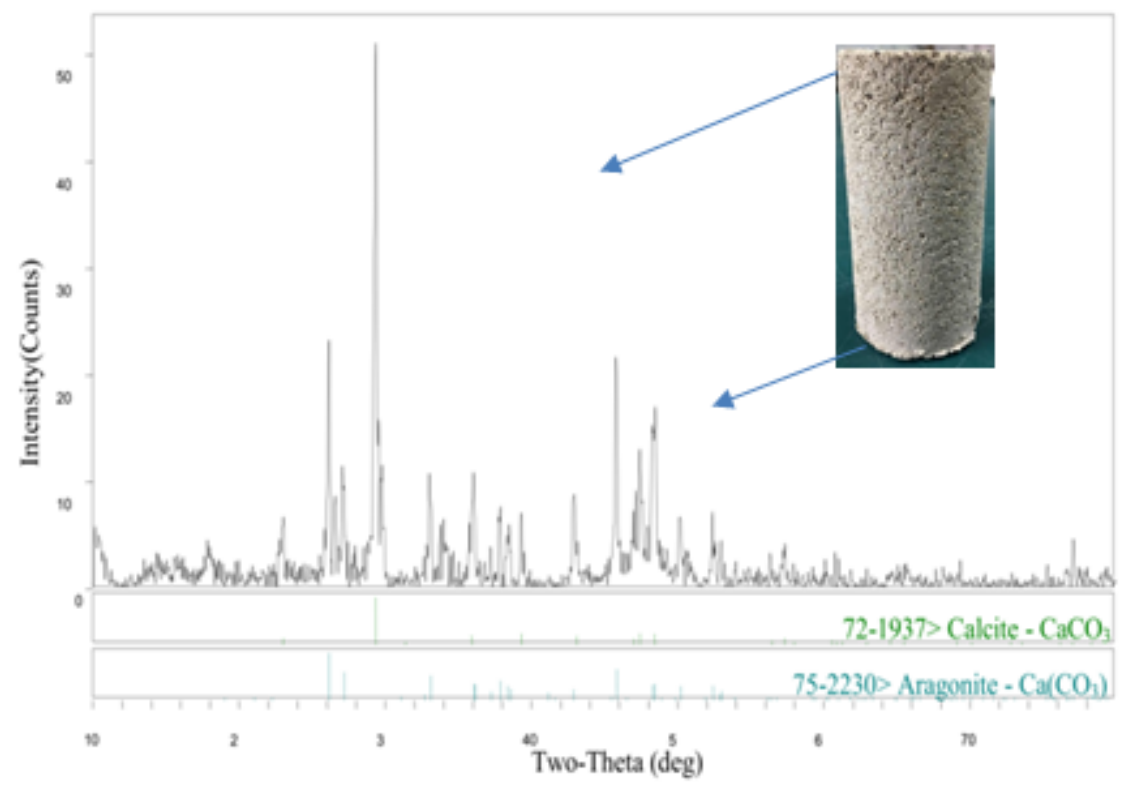

Figure 8

XRD pattern of the sand column cemented by microbial mineralization/carbonization method. 


\section{Figure 9}

XRD pattern of the sand column cemented by chemical carbonization method.

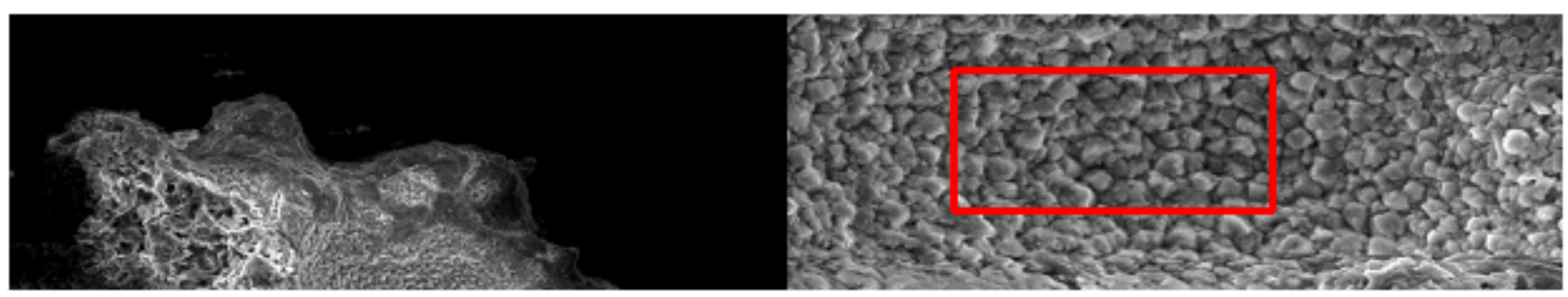

Figure 10

SEM images of sand columns: $(a, b)$ chemical carbonization; $(c, d)$ microbial mineralization/carbonization. 


\section{Figure 11}

The process of microbial carbonization/mineralization of loose calcareous sand particles (After Zhan, 2018).

\section{Figure 12}

Uniaxial compressive strength of sand columns cemented by chemical carbonization (a) and microbial mineralization/carbonization (b) methods.

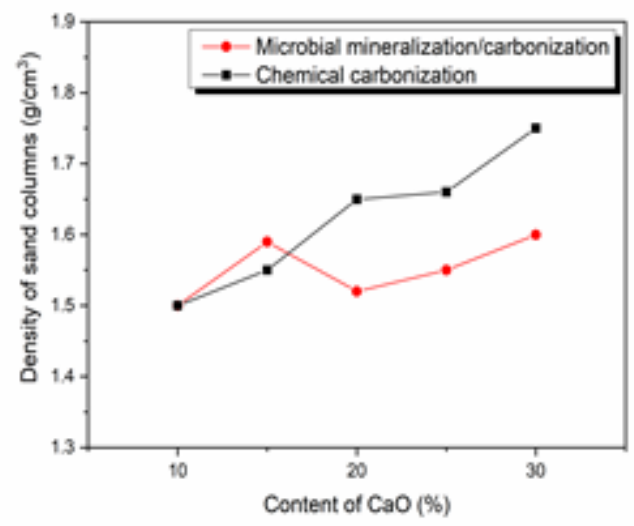

Figure 13

Average densities of sand columns prepared by chemical carbonization and biomineralization/carbonization.

\section{Figure 14}

Average permeability coefficient of sand columns: (a) pure sand column, (b) chemical carbonization, and (c) microbial mineralization/carbonization. 
Figure 15

Potential applications in the field of construction materials about the CAB.

\section{Supplementary Files}

This is a list of supplementary files associated with this preprint. Click to download.

- GA.doc 